\title{
24
}

\section{MEXICO \\ From simple and centralised to expansion, diversity and complexity}

\author{
Elaine Reynoso-Haynes, Susana Herrera-Lima, \\ Ana Claudia Nepote and Lourdes Patiño-Barba
}

\section{Introduction}

The roots of public communication of science (PCS) in Mexico may be traced back to the early days of science in the 17th century. However, as in other parts of the world, the modern era of PCS in Mexico started in the 1960s, and was basically concentrated in the urban area of Mexico City. There were four main pillars for the development of science communication during those early years: UNAM (National Autonomous University of Mexico), CONACyT (National Council for Science and Technology), AMC (Mexican Academy for Science) and SOMEDICyT (Mexican Society for the Communication of Science and Technology).

Today, various PCS products and activities are dispersed throughout Mexico in different formats, media and spaces. Many institutions and persons with different profiles are involved: state and private universities; the various state councils for science and technology; and government and NGO agencies, private companies, science journalists as well as freelance science communicators. Other activities related to the field are research, evaluation, professional training, management, administration and commercialisation. This chapter tells the story of those early years of PCS and how such projects have evolved. 


\section{The early years}

Although the modern era of PCS in Mexico started during the decade of the 1960 s as a result of institutionalised efforts, the roots of this activity, as in most countries, can be traced back to the early days of science. Science in Mexico is deeply rooted in the knowledge of the native people whose lives were closely linked to the physical and natural world. The Mayans had a profound knowledge of natural phenomena, such as the cycles of water, natural harvest cycles and the capacity to predict astronomical events. Such knowledge was important to them not only for practical applications such as agriculture but also for religious and political reasons. In 1521, Tenochtitlan, the heart of the Aztec empire (the present site of Mexico City) fell to the Spanish conquerors. Spanish rule would last almost three centuries, producing a unique clash and fusion of European and local culture, knowledge, experience and beliefs. When the conquerors arrived in these remote lands they were very much impressed by the collections of natural specimens (flora and fauna) and botanical gardens owned by the Tlatoanis (the Aztec rulers) for study, preservation and reproduction. Soon after the conquest, the Spanish rulers organised expeditions throughout the territory they called New Spain with the purpose of collecting, registering and studying specimens of flora and fauna, as well as finding archaeological treasures. This practice continued into the early 19th century, with some items sent to Spain and the rest of the collection retained for research and display at the Museum of Natural History when it opened to the public in 1790 (Rico Mansard, 2007).

During this period, scientific knowledge was shared with the general public. Outstanding examples are two books about comets written by Carlos Sigüenza y Góngora, based on the ideas of Copernicus, Galileo, Descartes and Kepler. The purpose of these books was to reassure people about a comet that appeared in 1680 . The popular belief was that comets were composed of exhalations from deceased bodies and human sweat and that they were precursors of calamitous events (Benítez, 1995).

Two other outstanding pioneers of popularisation of science in Mexico were José Antonio Alzate (1737-99) and Ignacio Bartolache (1738-90). Alzate was a priest who dedicated his life to research and writing articles for the general public on physics, chemistry, mathematics, astronomy, botany, archaeology, philosophy and literature. He was the founder of the first cultural newspaper in the New Spain (Enciclopedia de la literatura en México, 2019). 
Bartolache wrote about medicine, astronomy and mathematics. One of his most important contributions was how to deal with smallpox, and in 1772 he started the first publication for the general public about medicine and physics called Mercurio volante [Flying Mercury]. In 1769, both Alzate and Bartolache studied the transit of Venus in front of the Sun (Moreno, 2013).

Institutionalisation of science began shortly after the independence of Mexico from Spain in 1821. The first scientific society in the American continent and fourth in the world, the Mexican Geographical and Statistical Society was founded in 1833 with the purpose of making a map of the young republic, collecting national statistics and publishing a journal for the general public (Azuela Bernal, 2012).

During the 19th century, several publications for the general public appeared, some published by the scientific societies and museums. One of the most popular was Mosaico Mexicano (1843-46), which included news about scientific discoveries and natural phenomena along with poetry, historical events, practical agricultural advice, biographies of celebrities, descriptions of exotic places, balloon trips and short stories (Cuevas, 2002).

The National Museum contained collections of natural history, documents, machines and objects of scientific, artistic and religious interest. In 1825 , the director determined that the museum should have the double function of preservation and exhibition for the general public. Eventually, this collection would be split into several categories, including natural history. With this collection of natural specimens, the Museo de Tacubaya was opened in 1893 with the triple objectives of research, teaching and popularisation of science (Cuevas, 2002).

One of the most remarkable figures of the beginning of the 20th century was the astronomer Joaquín Gallo, head of the National Astronomical Observatory of Mexico for more than 30 years. He was very active in communicating science to the general public through talks and newspaper articles (Biro and Mateos, 2011).

The beginning of the 20th century was marked by the Mexican Revolution, a civil war from 1910 to 1920 . The war began as an attempt to overthrow the 34-year regime of Porfirio Diaz. Although Diaz's regime was known for the development of science, industry, infrastructure and foreign investments in Mexico, it was also known for being a dictatorship that favoured a very small and outrageously wealthy group of individuals while the majority of the population was living in extreme poverty. The years after the revolution were devoted to a total and profound reconstruction of Mexico. In 1920, José 
Vasconcelos, president of the National University of Mexico, proposed the creation of a federal ministry of education and launched an intensive literacy and educational campaign with several elements: an ambitious publishing effort, the creation of public libraries and the staging of cultural festivals for the population. His renovation project included what he called 'free discussions', seminars by the most important intellectuals and university professors, with the purpose of constructing a new identity for Mexico. One of the outcomes was the multifaceted movement known as 'Mexican Muralism' ${ }^{1}$ with famous painters such as Diego Rivera, David Alfaro Siqueiros and José Clemente Orozco (Fierro, 2003).

Science and science communication also had a recovery process after the revolution. An example is the Mexican Society of Natural History, the second oldest society in Mexico, founded in 1868 and lasting until 1914. In 1936, Alfonso L. Herrera and Enrique Beltrán decided to revive this society with the purpose of promoting scientific and traditional knowledge of nature in Mexico. Its journal became the most important science communication product about natural sciences in the 20th century (Gío-Argáez et al., 2013).

The following decades are known as the era of modernisation and industrialisation of Mexico as well as the development of higher education (Aguilar and Serrano, 2012). The international and national contexts were appropriate for the process of the institutionalisation of science and technology. The National Council for Higher Education and Scientific Research was created in 1935 (Casas, 1985). Later, in 1952, UNESCO (United Nations Educational, Scientific and Cultural Organization) showed an interest in the development of science and technology in Latin America. In 1963, the 'United Nations Conference for the Application of Science and Technology for the Development of Less Developed Regions' launched an innovative educational movement that stressed the importance of improving science education as well as increasing the level of science education of the population (Massarani et al., 2015, p. 13). Mexico was an emblematic and inspiring country for the Latin American region due to its process of institutionalisation and consolidation of science, which triggered the process of institutionalisation of science communication (Sánchez-Mora et al., 2015).

1 Mexican Muralism was an artistic movement, starting in the 1920s, in which social, historical and political messages were portrayed on murals as part of the efforts to reunify the country and create a national identity under the post-Mexican Revolution government. See www.khanacademy.org/ humanities/ap-art-history/later-europe-and-americas/modernity-ap/a/mexican-muralism-los-tresgrandes-david-alfaro-siqueiros-diego-rivera-and-jos-clemente-orozco. 


\section{The modern era of public communication of science in Mexico}

The modern era of PCS started in the 1960s. The term used at the time was divulgación de la ciencia, which has a definite deficit model approach. Today the preferred term in Mexico is comunicación pública de la ciencia, which includes a wide range of approaches.

The pillars of the early stage of the modern era were UNAM, CONACyT, AMC and SOMEDICyT (Reynoso-Haynes, 2015a).

\subsection{National Autonomous University of Mexico (UNAM)}

Previous to this modern era of science communication, UNAM had two outstanding examples of science communication: the Geology Museum (1906) and the Botanical Gardens of the Institute of Biology (1959), which still exist today.

However, the first attempts at the institutionalisation of science communication also occurred in UNAM by the physicist Luis Estrada. In 1968, with the support of students and a small group of colleagues, mostly from a scientific background, he launched a journal called Física [Physics] for physics teachers and university students. Two years later, this journal was renamed Naturaleza [Nature] with the purpose of offering a wider scope of scientific topics. The elaboration of this journal became a practical school for science communicators, as well as an arena for theoretical discussions related to the field (Estrada et al., 1981). In 1970, Estrada and his colleagues founded a department within the UNAM with the purpose of communicating science to non-experts. In 1980 it became the Programa Experimental de Comunicación de la Ciencia (PECC) [Experimental Program for Science Communication]; and the following year became the Centro Universitario de Comunicación de la Ciencia (CUCC) [University Centre for Science Communication], the first university institution in Mexico devoted completely to science communication (Zamarrón, 1994). In 1997, CUCC became the present Dirección General de Divulgación de la Ciencia (DGDC) [General Direction for the Popularisation of Science] (Sánchez-Mora et al., 2015).

The DGDC has two science museums (Universum, opened in 1992, and the Museum of Light, opened in 1996) and communicates science using a full range of media such as the magazine ¿Cómo Ves? It offers courses and workshops for teachers, children and the general public as well as postgraduate courses 
for training professional science communicators; organises and participates in a variety of PCS events and outreach programs; collaborates with research institutes and other museums within Mexico and abroad; and carries out studies and research in the field of PCS. ${ }^{2}$

Other PCS programs in UNAM include the publication of Ciencias [Sciences], a journal for university students published by the Facultad de Ciencias [School of Science] since 1980.

UNAM provides reliable information to news media with publications produced by different research institutes in different campuses in several states. It produces radio and television programs on scientific topics that are broadcast on commercial or cultural channels and stations as well as the UNAM's TV channel and radio station, and an increasing offering on the web (Sánchez-Mora et al., 2015).

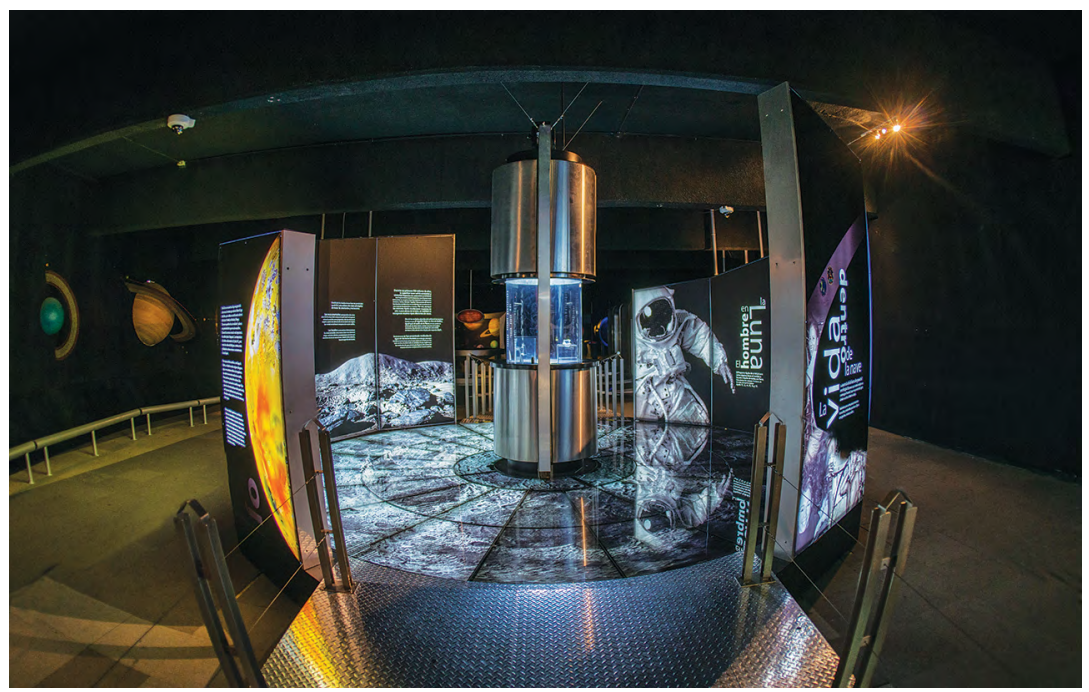

Figure 24.1: The exhibit of the lunar rock in the science museum Universum. This rock was collected by astronauts from Apollo 17 on 19 December 1972.

Source: Universum.

2 See www.dgdc.unam.mx. 


\subsection{National Council for Science and Technology (CONACyT)}

The second pillar of this modern era of PCS is CONACyT, founded in 1970. From the very start, this government agency communicated science to the general public as one of its duties. It produced two journals Ciencia y Desarrollo [Science and Development], aimed at the educated reader, and Información Científica y Tecnológica (ICyT) [Scientific and Technological Information] with a more popular science approach. CONACyT was a pioneer in offering a training course for science journalists (Sánchez-Mora et al., 2015).

CONACyT has always supported various PCS events, activities and products. In 2013 it launched a call for PCS projects with a multidisciplinary approach, to support the development of the field in different regions of the country.

\subsection{Academia Mexicana de Ciencias (AMC) [Mexican Academy for Science]}

The third pillar of the modern era is the AMC. In 1982, it started a form of science communication that became extremely popular: Domingos en la ciencia [Sundays in Science]. This series of informal talks by scientists and science communicators to the general public on a wide range of topics continues throughout the country to this day. Similar experiences are the Encuentros de divulgación científica [Encounters in Science Communication], an annual event since 1985 organised by the Sociedad Mexicana de Física [Mexican Society for Physics] in the city where the annual physics conference is held; and the 'Science and Technology Week' organised by the CONACyT every year since 1994 (Sánchez-Mora et al., 2015).

\subsection{Mexican Society for the Communication of Science and Technology (SOMEDICyT)}

The fourth pillar is SOMEDICyT, a network of professional science communicators founded in 1986. It started out with only 19 members located in the urban area of Mexico City, and today consists of full-time science communicators, scientists, teachers and journalists with 303 active members in 24 of the 32 states in the country. ${ }^{3}$ Products and activities of SOMEDICyT include books on science topics for children, peer publications in the field, the development of exhibitions and science museums and products on the

3 See www.somedicyt.org.mx. 
Internet. It has organised numerous national and international conferences and contributes to the professional development of the field by means of seminars, courses and workshops. SOMEDICyT offers an annual award to outstanding communicators and encourages young science communicators by organising contests for essays on different scientific topics (Reynoso-Haynes, 2015b).

Other publications appeared during this early stage such as Chispa [Spark] for children, Avances y Perspectiva [Advances and Perspectives] for the academic community, and Cuadernos de Nutrición [Notebooks on Nutrition] with an educational perspective. (Sánchez-Mora et al., 2015).

\section{The expansion and diversification of PCS in Mexico}

Most of the activities described above occurred in the urban area of Mexico City. Gradually, due to various factors, different projects appeared in other parts of the country.

The first factor is the creation of museums and science centres. Although traditional science museums have existed in Mexico since the 19th century, the first two hands-on science museums in Mexico were the Museo Tecnológico [Museum of Technology] in Mexico City founded in 1970 and the Centro Cultural Alfa [Alfa Cultural Centre] in Monterrey in 1978. In the 1980s, there was an international boom of interactive science museums and centres (Sánchez-Mora et al., 2015), and it reached Mexico between 1990 and 1996 with the opening of the first interactive museums in several cities as well as children's museums with an important component of science-related exhibits and activities. Most of these museums and science centres belong to the Asociación Mexicana de Museos y Centros de Ciencia y Tecnología (AMMCCyT) [Mexican Association of Science and Technology Museums and Centres] created in 1996. Through this network, its members collaborate, share exhibitions and stimulate professional growth (Sánchez-Mora et al., 2015; Padilla, 2000). AMMCCyT has 35 institutional members (Bonilla, 2016).

The second expansion factor is related to the incorporation of PCS activities into the agenda of REDNACECyT, the national network of state councils for science and technology, created in 1998 with the purpose of supporting the development of science and technology in Mexico's 32 states. $^{4}$ In 2012, a special fund was created within CONACyT to support and promote programs for the development of PCS in each of the 32 states. In some cases,

4 See www.rednacecyt.org. 
these funds strengthened the development and infrastructure of existing efforts, for other states it was a starting point. Examples of projects that have been supported with these funds are science museums, travelling exhibitions, science fairs and training programs for science communicators. One of the main purposes is to reach marginal and rural communities in remote areas (Padilla and Patińo, 2012).

The third ingredient of the territorial expansion of PCS was the creation of the National Week of Science and Technology funded and organised by CONACyT since 1994. Although PCS is not the main purpose for many of the participating institutions (universities, research institutes, businesses and government organisations), this annual event for the general public and students has been an important learning experience in PCS. In some states, the demand for such events and activities is so great that one week is not enough. Similar events are offered throughout the year, promoting a strong relationship between schools and science institutions.

Today, many institutions are involved in PCS: CONACyT, state councils of science and technology; universities, research institutions, scientific societies, museums, zoos, NGOs, communication media and SOMEDICyT (Padilla and Patińo, 2010).

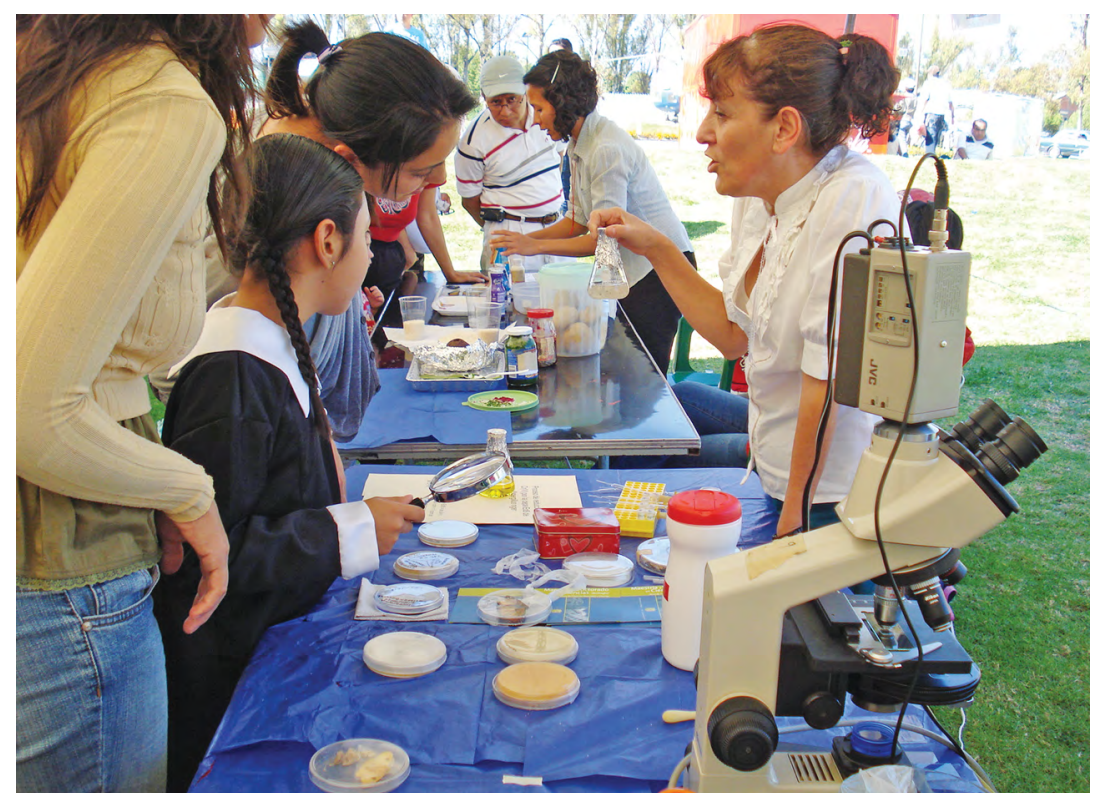

Figure 24.2: Outdoor science fair in the science centre Explora in León, Guanajuato.

Source: Lourdes Patiño-Barba. 
In the last 10 years, several new institutions and groups dedicated exclusively to PCS activities and projects have sprouted-mostly civil associations, businesses and independent groups of professionals and students. State networks of science communicators have been formed with the intention of creating a community of full- or part-time professionals in PCS and promoting professional training in the field (Patiño, 2018).

\section{Science journalism}

Science journalists are becoming a strong and independent professional community. This movement began in 1979 when Mexico hosted the Third Iberoamerican Conference of Science Journalism in Mexico City. The conference was organised by the Asociación Mexicana de Periodistas Científicos (AMPECI) [Mexican Association of Science Journalists], CONACyT and UNAM. Science journalists from Spain, Latin America and Mexico participated. The topics were: a) media and science communication, b) assessment of science journalism, c) training science journalists, d) social projection of science journalism, e) environment and science journalism (Asociación Mexicana de Periodismo Científico, 1981).

Thirty-seven years later, in 2016 the Red Mexicana de Periodistas de Ciencia (RedMPC) [Mexican Network of Science Journalists] was formed for professional science journalists and students. This network has over 100 members. In 2017, it was incorporated as member 55 in the World Federation of Science Journalists, a non-profit international association. This achievement is important to the RedMPC because now it has a voice in the global panorama of science journalism with the opportunity of collaborating with other professionals on different international projects. ${ }^{5}$

\section{Different profiles of science communicators in Mexico}

PCS in Mexico started out as a volunteer 'missionary' free-time occupation, often at a personal cost and opposed by colleagues who considered communicating science to be a waste of time and a distraction from more important tasks of research and teaching. Today the PCS community is rich and diverse, with a wide range of professional profiles and experiences. For some, it is a full-time profession; for others, it is a secondary or complementary activity to their main

5 See redmpc.wordpress.com. 
occupation. This second group includes scientists and persons who work in the media. Fortunately, the number of full-time specialised science communicators has increased significantly over the past two decades (Reynoso-Haynes, 2015a).

Due to its complexity as a multidisciplinary field, science communication professionals must specialise-for instance in a certain scientific discipline, or in audiences they address or the media they use. Usually this specialisation involves a combination of these elements. Therefore, within the group of fulltime science communicators, we find people with many different backgrounds: writers, reporters, scientists, journalists, museographers, photographers, designers, computer scientists, engineers, artists and educators. There are others who support this activity through public relations, promotion, marketing, administration and management (Reynoso-Haynes, 2015a).

Studies performed by Padilla and Patiño (2010, 2013, 2016 and 2017) show that the different profiles are a consequence of the process of institutionalisation. Some research institutions, universities and science councils have departments devoted to PCS with professional science communicators, definite work plans and budgets. Unfortunately, this does not occur in several states in Mexico.

\section{Official attitudes to PCS}

Universities may appear to be the ideal places for the development PCS projects. The first obvious advantage is the proximity to a strong and diverse community with the latest scientific knowledge and a critical approach in practically any field: experts with various creative and technical abilities and artists who can participate in PCS as advisors, creators or evaluators. Other advantages are the infrastructure, laboratories and technical equipment as well as the financial benefits of being able to use all these facilities with much lower costs.

However, Patiño, Padilla and Massarani (2017) and Padilla and Patińo (2012) reveal that in many cases PCS is still not considered a priority in research and higher education institutions, and that it is often considered a minor activity by authorities and part of the academic community. The greatest disadvantage that science communicators working in universities face is that they are judged by 'academic standards and benchmarks' designed for other professions such as scientists. The situation becomes more critical when not only are the criteria used to evaluate science communicators 'imported' from other fields, but also the evaluators themselves, usually scientists who know nothing or very little about science communication and are not trained in the field. Sometimes these 'imported evaluators' look down on science communication as a minor 
activity compared to research and teaching. Therefore, the issue of how to evaluate science communicators is particularly important to those who work in universities and research institutions (Reynoso-Haynes and Tonda, 2013).

A group within the DGDC has been working on a proposal that includes peer evaluation, criteria and parameters for an adequate and just evaluation for a wide spectrum of profiles of science communication professionals. The first results of these discussions can be found in the proceedings of conferences and formal communications such as Delgado et al. (2003), Reynoso-Haynes (2008) and, more recently, in the XIII RedPOP (Latin American Network for the Popularisation of Science and Technology) and XIX SOMEDICyT conferences (Bravo, Reynoso-Haynes and Tonda, 2013). Such discussions conclude that the evaluation of products and their producers is inseparable. Any scheme proposed for this purpose is based on a specific conception of science communication, which includes the objectives that are pursued, the image of science portrayed and the relationship we seek with the recipient of our products.

Patiño and Padilla (2017) also found that financial support for PCS is still scarce. The study shows that science journalism is centralised in Mexico City, although there are several outstanding efforts in other parts of the country. Over 50 per cent of the institutions that perform PCS activities do not have a specialised department or a formal year plan. Budgets for science journalism tend to be quite low compared for those other functions of the institution. Most of the institutions studied do not have formal registers of the impact of their PCS activities. Another problem they found is the difficulty of keeping trained staff in PCS because a considerable number of the persons involved are students or professionals who have other activities. This is particularly true in science museums and centres where those involved in PCS activities (such as museum guides) usually remain only for a short period of time (six months or a year).

\section{Professionalisation and training in PCS}

In Mexico the number of programs for professional training in PCS is increasing. Courses, workshops, postgraduate courses, specialties, master's and $\mathrm{PhD}$ degrees in PCS are now available in different regions throughout the country. However, this is still insufficient due to the rate at which this activity is growing and the need to train professional science communicators.

Reynoso-Haynes (2009) proposed a classification of science communicators by generations depending on what kind of training they had received. The first generation of science communicators, the pioneers of the modern era who 
mostly started during the late 1960s and the 1970s, did not receive any kind of professional training because formal courses in science communication did not exist in Mexico or abroad at that time. The only school for this pioneer group was practical experience. Most of them had scientific backgrounds and the rest had training and experience in non-scientific fields such as communication, literature, humanities and journalism. Those whose initial background was science had to acquire experience and skills in some communication media, and those who started out with a non-scientific background had to learn the science they required in order to collaborate with scientists. The professional science communicator did not exist.

Then a second generation of science communicators emerged. Due to the lack of specific training programs in science communication, those who had an initial professional training in one of the fields mentioned above might enrol in formal postgraduate studies or specialised courses in a complementary field considered useful for their work. As the field of PCS started to grow stronger and more diverse, so too did discussions about what was required to be a professional science communicator. The need to plan and design specialised courses to train science communicators became evident. At UNAM, both generations combined their expertise to develop and teach these courses. The result was the first specialised course in PCS in Mexico, the Diplomado en Divulgación de la Ciencia [Science Communication Diploma], offered every year since 1995 . This 240 -hour course was designed with the purpose of providing the required theoretical and practical tools to enable graduates to communicate science to the general public (Reynoso-Haynes, 2009). The demand for this course increases constantly, as does the number of requests the DGDC receives to offer similar courses in other institutions within Mexico and abroad. Continuous evaluation has been a fundamental instrument for the planning and updating of the course.

Other options are graduate and postgraduate degrees as well as subjects in undergraduate programs. Not all of these programs are devoted exclusively to training professionals in the various areas of PCS, but this activity is a substantial part of the curricula. Such is the case at the Instituto Tecnológico y de Estudios Superiores de Occidente (ITESO) [Western Institute of Technology and Higher Education] in the city of Guadalajara, Jalisco, that has offered a master's degree in science communication and culture since $1998 .^{6}$

Since 2003 the postgraduate program in Philosophy of Science offers a master's and a $\mathrm{PhD}$ with several terminal options, including one in science communication. Other examples of programs that include science

6 See posgrados.iteso.mx/maestria-filosofia-ciencias-sociales/. 
communication are the course in science journalism at the School of Political Science of the UNAM and the postgraduate courses offered at the Universidad Autónoma Metropolitana (UAM) Metropolitan Autonomous University. Each of these programs has its entrance requirements, curricula, durations and graduate profiles depending on different needs and approaches. Both the ITESO and the UNAM programs have a strong emphasis in developing research skills in the field. Other programs, such as the diplomados (postgraduate courses) offered by the UNAM, SOMEDICyT and other universities are much shorter and have a more practical approach (SánchezMora et al., 2015).

The new creative, intellectual and ethical challenges in the field of science communication increase day by day in complexity, richness and diversity. These include new theoretical and methodological contributions, a growing presence on the web, new proposals and approaches for communicating science, new media, as well as new professional options and needs. Based on the two UNAM experiences, the Diplomado en Divulgación de la Ciencia and the Science Communication branch of the Philosophy of Science Postgraduate Program (as well as present-day needs for professional development in the field in all its complexity), the Department of Training and Research within the DGDC is currently working on a project for a postgraduate Specialisation in Science Communication in collaboration with the School of Political and Social Sciences in UNAM. The purpose of this one-year, 640-hour program is to offer students a solid theoretical and methodological background as well as the opportunity for extensive practice in some area of personal interest (UNAM, 2018a).

Those who graduate from these specialised PCS programs constitute a third generation of science communicators.

\section{Research and evaluation in PCS}

Today PCS is considered an academic and professional field. According to Ana María Sánchez Mora (2010), the origins of institutionalised research can be traced back to 1988 when Luis Estrada coordinated a collective document with the title Aspectos de investigación en comunicación de la ciencia [Aspects of research in science communication]. It suggested that communication of science should be performed with a more professional and methodological approach and should have a multidisciplinary perspective. Certain research topics were proposed with the purpose of understanding and improving PCS products and activities by establishing a communicative bridge between the audience and scientific concepts through a process of re-creation of the 
initial scientific discourse. This includes a basic approach to the meaning of scientific culture, the problems related to language and the strategies used to communicate with non-specialists, and the need for evaluation of the effectiveness and originality of what is produced (Sánchez Mora, 2010, p. 119).

At the beginning of the 1990s a collection of books called Divulgación para Divulgadores [Science Communication for Science Communicators] emerged within the DGDC of UNAM with the purpose of sharing analysis, reflections and research related to PCS (Sánchez-Mora et al., 2015).

The proceedings of conferences of SOMEDICyT and RedPOP have published various studies in diverse fields of PSC, such as methodological proposals (Sánchez Mora, 1991) and the evaluation of the impact of journals (Tonda and Burgos, 2007). Research carried out in science museums and centres are the most numerous and have contributed considerably to our understanding of the role such environments and their activities play in science literacy as well as how and what people learn. A good part of these research projects has been carried out in UNAM's museums Universum and the Museum of Light (Sánchez-Mora et al., 2015).

This kind of research will significantly contribute to the development of improved frameworks for practice and evaluation in museums and will also provide a basis for future research. There are many examples of this kind of research in Reynoso-Haynes (2000, 2001, 2003), Lozano (2005), Rico Mansard (2009) and Sánchez-Mora (2002, 2006, 2009a, 2009b, 2012).

Initially research in PCS in Mexico arises from within the community of science communicators, but gradually professionals from other disciplines have become interested in the field. Today we can find research projects in PCS with different approaches such as communication, sociology, education, literature and social studies in science.

Another fundamental ingredient of the process of professionalisation and research in PCS is the emergence of international journals in science communication. The issues covered in these journals have had a definite impact on academic discussions in Mexico. For instance, the public communication of science approach, which leans towards the democratisation of knowledge and the empowering of citizens in scientific and technological matters has been significantly displacing that of the 'deficit model'. This can be seen in articles and theses written by professionals in Mexico and Latin America such as Merino and Roncoroni (2000), Caue (2002), Lozano (2005), Cevallos (2008) and Reynoso-Haynes (2012) (in Sánchez-Mora et al., 2015). 
The two most important examples of postgraduate programs preparing future researchers in the field are the Master's in Communication of Science and Culture of ITESO in Guadalajara, Jalisco; and the science communication strand of the master's and PhD in Philosophy of Science at UNAM. The first one began in 1998 and approaches the study of science communication from a social and cultural perspective, considering the relationship between science, the media, the spaces, the institutions and the social interactions. The second one, the science communication strand of the postgraduate course in Philosophy of Science, began in 2003. The approaches in this program are philosophy and history of science; social studies in science; and science, technology and society.

Other examples of research with different disciplinary approaches are the projects developed by Ernesto Márquez, Jorge Padilla with Lourdes Patiño, and Elaine Reynoso-Haynes. Márquez and Tirado (2009) use a psychological approach to analyse the perceptions that Mexican teenagers have towards science and technology. Patiño and Padilla use different approaches to analyse the state of scientific culture in urban populations: first a psychological and sociological approach (Padilla and Patiño, 2011) and then one in which they consider the inclusion of science in the context of habits of cultural consumption (Patiño and Padilla, 2017). Reynoso-Haynes (2012) uses an educational approach to analyse the learning processes in museums and how these institutions can contribute to the construction of scientific culture, and proposes a working framework for the development and evaluation of science museums.

Another important line of research is that of diagnosis of PCS in different states in Mexico. These studies have been required and financed by CONACyT, the state councils for science and technology and SOMEDICyT. Using basically quantitative methodologies, these studies have provided useful information related to different aspects of PCS in Mexico (Padilla and Patińo, 2010, 2012, 2014, 2016). In 2017 in coordination with the RedPOP, Patińo and Padilla conducted a diagnosis of the popularisation of science in Latin America (Patiño, Padilla and Massarani, 2017).

The evaluation of products and research in PCS are closely related. The issue of evaluating science communication products and activities is an old, but at the same time contemporary, debate. A Latin American contribution to this discussion can be found in the proceedings of a workshop held in 2006 in Cartagena, Colombia, in which several experiences and proposals related to the evaluation of products and activities in this field were presented (Lozano and Sánchez-Mora, 2008). 


\section{PCS publications}

There are several journals or popular science magazines published by universities, CONACyT and the state councils of science and technology. Most of these magazines are for readers with a high school or university educational level and a few are for children. ${ }^{7}$

As for books, we consider two categories of PCS publications: the PCS literature about different scientific issues for non-experts, and the literature about PCS issues for those interested in the field.

In 1986 the publishing house Fondo de Cultura Económica launched an ambitious editorial project: a collection of books on different scientific topics written by Mexican scientists and science communicators called La ciencia desde México [Science from Mexico]. In 1997, having reached 157 titles, the collection became international and its name was changed to La ciencia para todos [Science for Everyone], with the purpose of including authors from other Spanish-speaking countries (Farías, 2002). To date, the collection has more than 250 titles, and several have been re-edited (Torres, 2018).

The DGDC has several collections of books for the general reader that have served as a support to science students and professors of all educational levels due to the variety of scientific topics and issues. ${ }^{8}$

The SOMEDICyT also has collections for the general reader such as: Colección Básica de Medio Ambiente [Basic Collection of the Environment] and a collection of children's books about health (Reynoso-Haynes, 2015b).

As for peer publications for science communicators or those interested in the field, the two main contributors in Mexico are the DGDC of the UNAM and the Master of Science and Culture program of the ITESO. Both institutions publish collections of books that cover different professional aspects as well as trends in research issues in PCS.

7 Examples are: Ciencia y desarrollo (CONACyT), Ciencias (UNAM), ¿Cómo Ves? (UNAM), Elementos (Autonomous University of Puebla), Ciencia (AMC), Hypatia (University of the State of Mexico) and Conversus (National Polytechnic Institute).

8 Examples are: the collection Antologias ¿Cómo Ves, which consist of articles originally published in the journal ¿Cómo Ves? during its 20 years of existence with topics such as physics, mathematics, chemistry, astronomy and the environment. Other collections are Divulgación para profesores [Science Communication for Teachers], Ojitos Pajaritos for children, Science and Art, History of Science, Agenda ciudadana de ciencia y tecnologia [Citizen Agenda for Science and Technology] a collection of 10 books with challenges in which science and technology has solutions that citizens should know and several ebooks and co-editions with other institutions (www.dgdc.unam.mx/libros). 
Some of the topics addressed in the collections of the DGDC are research and evaluation in museums, scientific journalism, current debates in PCS and social, philosophical and historical studies related to science communication. ${ }^{9}$

The ITESO collections, created and coordinated by Susana Herrera and Carlos Enrique Orozco since 2000, are the result of research projects of their academic community. The titles of these collections are De la Academia al Espacio Público [From the Academia to the Public Space] and Comunicar Ciencia en México [Communicating Science in Mexico]. ${ }^{10}$

There are also examples of international collaborations with other networks such as RedPOP (the Latin American Network for the Popularisation of Science and Technology) and books coordinated by Juan Nepote and colleagues from other countries. ${ }^{11}$

Elaine Reynoso-Haynes as president of the SOMEDICyT (2012 -14) coordinated a two-volume work with the title Hacia dónde va la Comunicacion Pública de la Ciencia [Where is Public Communication of Science in Mexico Going?]. In these books the status of PCS in Mexico is presented as well as the main issues, discussions and proposals in the field. The first volume describes the origins and the institutions of PCS in Mexico and the second one presents the status of the professional field of PCS. These books, which were published in 2015, are the result of a collective effort of 27 authors covering a large range of experiences and the national challenges in PCS. The purpose of these books was to provide proposals for public policies (Reynoso-Haynes, 2015a, 2015c). ${ }^{12}$

9 See www.dgdc.unam.mx/libros/. Collections of books for science communicators are: Divulgación para divulgadores [Science Communication for Science Communicators], Museos de la $D G D C$ [Musuems of the DGDC].

10 The titles of some of the chapters of these books represent a sample of the different research projects. For example, in 2012 professionalisation, public policies; magazines, films and museums; in 2015, communication and scientific culture; historical and social role of science; activism and science and social problems in marginal regions; in 2016, trends in PCS, audio-visual discourse and environment and health; and, in 2018, research in PCS and environmental communication and literature, science and theme parks.

11 In 2009 Juan Nepote and Paola Rodari wrote a book called Más allá del océano. Ciencia y ciudadanos en Jalisco y Trieste [Beyond the Ocean: Science and Citizens in Jalisco and Trieste], which discusses the similarities and differences in the construction of scientific culture in both countries. A second book is Instrucciones para Contagiar la Ciencia [Instructions to Infect you with Science] coordinated by Juan Nepote and Diego Golombek from Argentina, which contains articles where 29 Mexican and Argentinian authors share their stories about how they engage people in science in museums, schools, books, journals and several other projects.

12 These books were part of a large project launched in February 2012 by the AMC, CONACyT and the Advisory Council in Science for the President of Mexico with the purpose of analysing the state of science in Mexico in the international context with the intention of presenting specific proposals for the development of the country. More than 100 panels of experts of different branches of science took place in different cities. The results of all these discussion groups were published in a series of books with the title Hacia dónde va la ciencia en México [Where is Science in Mexico Going?]. 


\section{The future and challenges of science communication in Mexico}

In the article 'Public Communication of Science in Mexico: Past, Present and Future of a Profession' (Sánchez-Mora et al., 2015), several challenges and possible solutions were proposed. These were based on an analysis of how the field has evolved in Mexico and also internationally; the growing body of knowledge; the increasing need as well as the diversification of objectives for communicating science to different sectors of the population; the wide scope of objectives and the changing strategies and media; and the need to strengthen the professional field of PCS.

These proposed challenges were classified into three categories:

\subsection{The challenges related to the national context}

Although the need to incorporate science into the general culture of the population is recognised as urgent, the activities and programs to achieve this goal have not received an adequate level of acceptance and support from decision-makers and society as a whole. A greater presence in the media is necessary, coupled with more opportunities for encounters between experts and citizens so the latter can learn and participate in debates on matters related to scientific knowledge and how it impacts on their personal and collective lives. In order to reach this goal, collaboration between several sectors of society is required: researchers, teachers, industry, the media and decisionmakers. The community of science communicators will act as intermediaries between all these sectors and the public.

The starting point for this collaboration is an analysis of the meaning of scientific culture and its link to society. Some of the issues to be tackled are the goals and objectives of a scientific culture for the population, the necessary basic knowledge and skills needed to fulfil these goals and objectives, and the attitudes and values that should be promoted when applying this knowledge (Reynoso-Haynes, 2007).

The balance between global and local issues is fundamental. The use of a 'glocal' model for science communication - based on combining global knowledge and its application to the local context, and considering local interests, problems, solutions and expertise-is highly advisable in cases in which citizen engagement is critical. This includes issues related to public health, environmental problems and climate change (Reynoso-Haynes, 2003, 2005). 


\subsection{The challenges related to the institutional context}

Most science communicators in Mexico work in universities, higher education or state institutions. Unfortunately, due to the relative youth of the profession, programs, projects and groups in these institutions, they are vulnerable to political and institutional changes. A clear mission and strategies to guarantee their stability is required. Programs should not be attached to one specific administration or to political interests but to long-term plans framed within an institutional project. The project must be based on a collective analysis of the need to integrate science with the general culture of the population as well as the role of the community of science communicators in this task. Institutions need to have clear guidelines and plans for their development, including criteria for hiring, promotions, permanence and professional growth of its personnel. Different types of profiles for science communicators should be established with the purpose of facilitating these decisions. At the same time, the personnel hired must be evaluated using fair and relevant criteria based on the work they perform.

\subsection{The challenges inherent to the activity}

Issues such as the definition of the required scientific culture for the Mexican population and our social responsibility to and relationship with our audience must be dealt with. This area requires further contributions to the field of knowledge, with proposals of new theoretical and methodological foundations, studies, experimentation and evaluation.

Parameters must be established for evaluating products and activities for the purpose of learning and improving, not grading or legitimising. These tasks should not be viewed as 'intellectual luxuries' but as essential instruments for communicating science effectively, with quality and responsibility. Such activities should be seen as fundamental to the successful development of projects and be given full institutional support.

Last but not least, professionalisation requires the support of postgraduate studies, postgraduate courses, courses to learn new topics or skills, workshops, exchange programs and participation in forums and conferences. 


\section{Conclusions}

Public communication of science in Mexico began in the 17th century as a consequence of the need to acculturate the 'New World' with the Western worldview introduced by the Spanish conquerors. Such efforts continued, with outstanding examples, well into the 20 th century.

In the mid-20th century, an institutionalised government and academic effort took place with the purpose of strengthening science and technology throughout the country. As part of this movement it soon became evident that PCS was necessary with the objective of incorporating science into the general culture of the population. In the last couple of decades, PCS has flourished and expanded throughout Mexico with a wide and diverse range of programs, activities, science museums and centres, supported by professional networks and various programs for training science communicators. The growing PCS community is now composed of full-time science communicators, scientists, journalists and others from various backgrounds.

During the last decade, one of the main issues discussed by this community is how to better 'professionalise' the field. Diverse opportunities for specialised training are required as well as social and organisational structures that support and recognise PCS as a profession. PCS should be considered as a legitimate and therefore paid occupation, the same as other professional activities such as research and teaching. Although there are still a lot of people who participate in PCS activities as a part-time and voluntary job, there has been an increasing movement towards creating specialised PCS departments, mostly within universities and science and technology councils.

Terms such as 'science communication' or 'popularisation of science' are becoming quite common thanks to the participation of hundreds of science communicators in the mass media (TV, radio, internet, newspapers and journals) as well as massive events such as science fairs. The reasons for communicating science to the general public have also increased and become much more diverse. These commonly include an emphasis on the relationship between science and society, and also promote a culture that is compatible with science (as suggested by Cereijido (2016)).

Another reason for communicating science is to promote critical thinking in order to provide society with the criteria to identify fake news and to decide about pseudoscientific issues, such as whether or not to use 'miracle products' based on so-called scientific facts and popular practices that can be harmful to individuals or society as a whole. 
The increasing interest for PCS, as well as the growing number of organisations, networks and people involved in this endeavour may appear to be a positive sign for the field; however, it is not devoid of challenges. Consensus must be achieved among all those involved based on shared knowledge, experience and resources with the purpose of creating alliances and collaborations that will result in greater impacts and better communication with society.

Evaluation of the impact of products, programs and activities is essential. Evaluation must be incorporated and extended throughout the country with the purpose of learning and improving our professional activity. Therefore, time and resources for evaluation must be considered as a necessary ingredient of every project. Last but not least, research and researchers in the field must be supported not only with the intention of contributing to growing field of knowledge but also with the purpose of providing new strategies and methodologies for science communication.

\section{References}

Aguilar, E. and Serrano, P. (2012). Posrevolución y estabilidad. Cronología 1917 -1967. México: Instituto Nacional de Estudios Históricos de la Revolución Mexicana (INHERM). Retrieved from inehrm.gob.mx/work/models/inehrm/ Resource/437/1/images/posrevolucion_estabilidad.pdf.

Asociación Mexicana de Periodismo Científico. (1981). Memorias del III Congreso Iberoamericano de Periodismo Científico. México: AMPCI.

Azuela Bernal, L. F. (2012). La Sociedad Mexicana de Geografía y Estadística, la organisación de la ciencia, la institucionalisación de la Geografía y la construcción del país en el siglo XIX. Investigaciones Geográficas, 52. doi.org/10.14350/rig.30346.

Benítez, L. (1995). Carlos de Sigüenza y Góngora: Criollo, nacionalista y moderno hombre de ciencia. Instituto de Investigaciones Filosóficas, Universidad Nacional Autónoma de México. Retrieved from www.iifilologicas.unam.mx/pnovohispano/ uploads/95sabernovo/art29_95.pdf.

Biro, S. and Mateos, G. (2011). Astronomía para todos: Joaquín Gallo en el Observatorio Astronómico Nacional (1915 - 1946). In J. Bartolucci (ed.), La Saga de la Ciencia Mexicana (pp. 189-212). Coordinación de Humanidades, Universidad Nacional Autónoma de México.

Bonilla, A. (2016). Asociación de museos y centros de ciencia renueva mesa directiva. CONACyT prensa. Retrieved from www.conacytprensa.mx/index.php/sociedad/ museos/5039-ammccyt-renueva-mesa-directiva-apostara-por-divulgacion-de-laciencia. 
Bravo, A., Reynoso-Haynes, E. and Tonda, J. (2013). La evaluación de los divulgadores de la ciencia: La experiencia de la Dirección General de Divulgación de la Ciencia (DGDC) de la Universidad Nacional Autónoma de México (UNAM). In Proceedings of the XIII Reunión de la RED POP and XIX Congreso Nacional de Divulgación de la Ciencia de la SOMEDICyT (pp. 79-88). Zacatecas, Mexico. Retrieved from www.redpop.org/redpopWeb/Contenido/Pagina/File/LIBRO\%20 SOMEDICYT\%20ok.pdf.

Calvo Hernando, M. (1999). El Nuevo Periodismo de la Ciencia. CIESPAL, Quito.

Calvo Hernando, M. (2005). Ciencia y Periodismo Científico en Iberoamérica. Conferencia de apertura en el II Congreso Iberoamericano de Comunicación Universitaria y I Reunión Iberoamericana de Radios Universitarias. España.

Casas, R. (1985). El estado y la política de la ciencia en México (1935 - 1970). Cuadernos de Investigación Social, 11. Instituto de Investigaciones Sociales, Universidad Nacional Autónoma de México.

Caue, M. (2002). Apresentação. In Ciência e Inclusão Social, Estação da Ciência. São Paulo, Brasil: Universidade de São Paulo, Fondo de Cultura e Extensão Universitária da Pro-Reitoria de Cultura e Extensão.

Cereijido, M. (2016). Hacia una cultura compatible con la ciencia. Retrieved from www.ccciencias.mx/es/ciencia-y-opinion/item/35-hacia-una-cultura-compatiblecon-la-ciencia.html.

Cevallos, M. (2008). Monitoreo y evaluación de la divulgación científica. In L. Massarini and C. Polino (eds), Los desafios y la evaluación del periodismo cientifico en Iberoamérica: Jornadas iberoamericanas sobre la ciencia en los medios masivos. Santa Cruz de la Sierra, Bolivia: AECI, RICYT, CYTED, SciDev.Net, OEA.

Cuevas, C. (2002). Historia y divulgación de la ciencia en México. In Dirección General de Divulgación de la Ciencia (ed.), Antología de la divulgación de la ciencia en México (pp. 121-29). México: Universidad Nacional Autónoma de México, México.

Delgado, S., Orta, A. and Heine, C. (2003). La evaluación de la divulgación científica: un reto por la calidad. In XII Congreso Nacional de la SOMEDICyT y VIII Reunión de la Red POP. México. Retrieved from www.somedicyt.org.mx/images/ divulgadores/congresos/12/memorias/Memorias/resumenes/profesionalizacion/ resumen_perez.htm.

Enciclopedia de la literatura en México. (2019). José Antonio Alzate. Retrieved from www.elem.mx/autor/datos/107001.

Estrada, L. (1988). Aspectos de investigación en comunicación de la ciencia (unpublished).

Estrada, L. et al. (1981). La divulgación de la ciencia. Cuadernos de Extensión Universitaria, México. Universidad Nacional Autónoma de México (UNAM). 
Farías, M. (2002). La ciencia para todos: 17 años de una aventura cientifica. México: Fondo de Cultura Económica.

Fierro, R. (2003). Templo Máximo de San Pedro y San Pablo. Museo de la Luz. 400 años de historia. México: Dirección General de Divulgación de la Ciencia, UNAM.

Gío-Argáez, R. et al. (2013). Revista de la Sociedad Mexicana de Historia Natural. Sistema de Información Ciencias. Facultad de Ciencias, UNAM, México. Retrieved from repositorio.fciencias.unam.mx:8080/xmlui/handle/11154/139857.

Golombek, D. and Nepote, J. (2016). Instrucciones para Contagiar la Ciencia. México: Editorial Universitaria. Universidad de Guadalajara.

Herrera-Lima, S. and Orozco, C. (eds) (2012). De la academia al espacio público. Comunicar ciencia en México. México: ITESO. doi.org/10.2307/j.ctvjk2v1q.16.

Herrera-Lima, S. and Orozco, C. (2018). Comunicar ciencia en México. Prácticas y escenarios. México: ITESO. doi.org/10.2307/j.ctvjk2vtt.

Herrera-Lima, S., Orozco, C. and Quijano, E. (2015). Comunicar ciencia en México. Discursos y espacios sociales. México: ITESO. doi.org/10.2307/j.ctvjk2vsb.1.

Herrera-Lima, S., Orozco, C. and Quijano, E. (2016). Comunicar ciencia en México. Tendencias y narrativas. México: ITESO.

Ledesma, I. (2013). La Biología y los biólogos en México: ciencia, disciplina y profesión. In M. Kleiche-Dray et al. (eds), La institucionalisación de las disciplinas cientificas en México. Siglos XVIII, XIX y XX: estudios de caso y metodología (pp. 99 -126). México: UNAM.

Lozano, M. (2005). Hacia un nuevo contrato social: la popularisación de la ciencia y la tecnología (Master's thesis). Universidad Nacional Autónoma de México UNAM, México.

Lozano, M. and Sánchez-Mora, C. (eds). 2008. Evaluando la comunicación de la ciencia. Una perspectiva latinoamericana, México D.F.: CYTED, AECI, DGDC-UNAM. Retrieved from www.redpop.org/wp-content/uploads/2015/06/Evaluando-lacomunicacin-de-la-ciencia.pdf.

Márquez, E. and Tirado, F. (2009). Percepción social de la ciencia y la tecnología de adolescentes mexicanos. Revista Iberoamericana de ciencia, tecnología y sociedad, 2, 1-19.

Massarani, L. (ed.) (2015). Guía de centros y museos de ciencia de América Latina y el Caribe. Brasil: RedPOP, Museu da vida, UNESCO, Biblioteca de Educacao e Divulgacao Científica Iloni Seibel.

Massarani, L. et al. (2015). RedPOP: 25 years of a Science Communication Network in Latin America. Journal of Science Communication, 14(03). doi.org/ 10.22323/2.14030406. 
Merino, G. and Roncoroni, M. (2000). La popularización de la ciencia y la tecnología, reflexiones básicas: un marco para la equidad (Serie Pedagógica). La Plata, Argentina: FHCE.

Moreno, M. A. (2013). Ciencia y arte en dos publicaciones astronómicas novohispanas del siglo XVIII. Anales del Instituto de Investigaciones Estéticas, 35(102). 11-31.

Nepote, J. and Rodari, P. (eds) (2009). Más allá del oceáno: Ciencia y ciudadanos. México: Coecytjal, SISSA Medialab, CULagos Universidad de Guadalajara. Ediciones Arlequín.

Padilla, J. (2000). Desarrollo de los museos y centros de ciencia en México. In J. A. Chamizo (coord.), Encuentros con la ciencia. El impacto de los museos y centros de ciencia. México, D.F.: Ed. AMMCyT y Conacyt.

Padilla, J. and Patiño, M. D. L. (2010). Diagnóstico de la difusión y la divulgación de la ciencia en Michoacán. Consejo Estatal de Ciencia y Tecnología de Michoacán, Morelia, Michoacán, México.

Padilla, J. and Patiño, M. D. L. (2011). Investigación sobre cultura cientifica, percepción y apropiación social de la ciencia en Michoacán. Reporte técnico. Consejo Estatal de Ciencia y Tecnología de Michoacán. Morelia, Mich.

Padilla, J. and Patiño, M. D. L. (2012). Fortalecimiento de la apropiación social de la ciencia y la tecnología en los estados - 2012. Reporte de evaluación, Red Nacional de Consejos y Organismos Estatales de Ciencia y Tecnología (REDNACECYT) y CONACyT. México, D.F.

Padilla, J. and Patiño, M. D. L. (2013). Diagnóstico de la divulgación de la ciencia en Guanajuato. Consejo de Ciencia y Tecnología del Estado de Guanajuato, Guanajuato, Gto.

Padilla, J. and Patiño, M. D. L. (2014). Diagnóstico de la divulgación de la ciencia en Querétaro. Consejo de Ciencia y Tecnología del Estado de Querétaro, Querétaro, Qro.

Padilla, J. and Patiño, M. D. L. (2016). Diagnóstico de la divulgación de la ciencia en Hidalgo. Consejo de Ciencia, Tecnología e Innovación del Estado de Hidalgo, Pachuca, Hgo.

Patiño, M. D. L. (2015). Motivos de afiliación y satisfacción de socios de Somedicyt. Internal document of Somedicyt. México.

Patiño, M. D. L. (2018). Retos para la comunicación pública de la ciencia. Speech presented at Coloquio de Centros de Pensamiento, Ciudad de Panamá, Pan. 5 April.

Patiño, M. D. L. and Padilla, J. (2017). Evaluación del impacto de las acciones de divulgación de la ciencia y la tecnología en el estado de Hidalgo. Consejo de Ciencia, Tecnología e Innovación del Estado de Hidalgo, Pachuca, Hgo. 
Patińo, M. D. L., Padilla, J. and Massarani, L. (2017). Datos de instituciones mexicanas. In Diagnóstico de la Divulgación de la ciencia en América Latina: Una mirada a la práctica en el campo. RedPOP-UNESCO y Fibonacci - Innovación y Cultura Científica, A.C. León, Gto - México.

Red Mexicana de periodistas de ciencia. (2018). Red Mexicana de periodistas de ciencia. Periodistas y comunicadores de ciencia. Retrieved from redmpc.wordpress.com.

Reynoso-Haynes, E. (2000). El Museo de las Ciencias: un apoyo a la enseñanza formal (Master's thesis). Facultad de Filosofía y Letras, Coyoacán, México, Universidad Nacional Autónoma de México UNAM.

Reynoso-Haynes, E. (2001). La evaluación de la divulgación de la ciencia. Speech presented at Rountable 'La evaluación de la divulgación de la ciencia', X Congreso Nacional de Divulgación de la Ciencia, Toluca, Estado de México, 7-9 March.

Reynoso-Haynes, E. (2003). La responsabilidad del divulgador en la formación de una cultura científica nacional. Speech presented at Rountable 'Cultura científica y cambio social', VIII Reunión de la Red Pop (Red de Popularisación de la Ciencia y la Tecnología de Latinoamérica y el Caribe), León, México, 26-29 May.

Reynoso-Haynes, E. (2005). Going glocal: UNAM's approach to global science. Dimensions (Bimonthly News Journal of the Association of Science and Technology Centres), 5 (September/October), 5-9.

Reynoso-Haynes, E. (2007). Entre lo global y lo local: hacia la construcción del contexto glocal para popu $\neg$ larisar la ciencia. In Memorias de la X Reunión de la Red Pop, Speech presented at X Reunión de la Red Pop (Red de Popularisación de la Ciencia de Latinoamérica y el Caribe). San José, Costa Rica, 9-11 May. Retrieved from www.cientec.or.cr/pop/2007/MX-ElaineReynoso.pdf.

Reynoso-Haynes, E. (2008). La evaluación de los comunicadores de la ciencia: una perspectiva mexicana. Razón y Palabra: Primera Revista Digitalisada en Iberoamérica Especialisada en Comunicología. 65. Retrieved from www.razony palabra.org. mx/N/n65/actual/ereynoso.html.

Reynoso-Haynes, E. (2009). A graduate course for science communicators: A Mexican approach. Journal of Science Communication 8(1). doi.org/10.22323/ 2.08010304 .

Reynoso-Haynes, E. (2012). La cultura científica en los museos en el marco de la educación informal (PhD thesis). Facultad de Filosofía y Letras, UNAM.

Reynoso-Haynes, E. (2015a). Introducción. Comunicación pública de la ciencia: Origen e instituciones. In Hacia dónde va la Ciencia en México (pp. 13-20). 17. CONACYT, Academia Mexicana de Ciencias and Consejo Consultivo de Ciencias. México, D.F., México. 
Reynoso-Haynes, E. (2015b). La Somedicyt y el desarrollo de la comunicación pública de la ciencia en México, in Comunicación pública de la ciencia: Origen e instituciones. Hacia dónde va la Ciencia en México. 17, p. 65. CONACYT, Academia Mexicana de Ciencias and Consejo Consultivo de Ciencias. Mexico, D.F., Mexico.

Reynoso-Haynes, E. (2015c). Comunicación pública de la ciencia: El oficio. Hacia dónde va la Ciencia en México. 18. México: CONACYT, Academia Mexicana de Ciencias and Consejo Consultivo de Ciencias.

Reynoso-Haynes, E., Monterrosa, C. and Macías, P. (2015). La formación de comunicadores de la ciencia en América Latina. In L. Massarani et al., RedPOP: 25 años de popularisación de la ciencia en América Latina. Museu da Vida, Casa Oswaldo Cruz, Fio Cruz-COC.

Reynoso-Haynes, E. and Tonda, J. (2013). Consideraciones generales sobre la evaluación de los divulgadores de la ciencia. Speech presented at Rountable La Evaluación de los Divulgadores de la ciencia. In Proceedings of the XIII Reunión de la RED POP and XIX Congreso Nacional de Divulgación de la Ciencia de la SOMEDICyT Zacatecas, Mexico. Retrieved from www.redpop.org/redpopWeb/Contenido/Pagina/File/ LIBRO\%20SOMEDICYT\%20ok.pdf.

Rico Mansard, L. (2009). Aportes a la museología mexicana. Coyoacán, México: Dirección General de Divulgación de la Ciencia (DGDC), Universidad Nacional Autónoma de México (UNAM).

Rico Mansard, L. (2007). La historia natural tras las vitrinas. In Museología de la ciencia: 15 años de experiencia (pp. 37-66). Dirección General de Divulgación de la Ciencia, Universidad Nacional Autónoma de México, México, D.F.

Sánchez Mora, A. M. (1991). La mancuerna investigador-divulgador. In Memorias del I Congreso Nacional de Divulgación de la Ciencia, 18-20 April. SOMEDICyT, Morelia, México.

Sánchez Mora, A. M. (2010). Introducción a la comunicación escrita de la ciencia. México: Universidad Veracruzana. doi.org/10.25009/uv.2006.131.

Sánchez-Mora, C. (2002). El Museo como foro educativo. Perspectivas Docentes. 27. México: Universidad Juárez Autónoma de Tabasco.

Sánchez-Mora, C. (2006). Las visitas guiadas en los Museos de Ciencias. Museolúdica. Revista del Museo de la Ciencia y el Juego, 8(4-15).

Sánchez-Mora, C. (2009a). La evolución educativa de los museos de ciencia. Ciencia y Desarrollo, 35(236).

Sánchez-Mora, C. (2009b). La potencialidad educativa no formal de los museos universitarios. Gaceta de Museos del INAH, 46, 28-34. 
Sánchez-Mora, C. (2012). Estudio de patrones de lectura de textos en museos: una contribución a la evaluación formativa de las cédulas. Boletin Cientifico y Cultural del Museo Universitario de Medellín, Colombia, 25, 81-90.

Sánchez-Mora, C., Reynoso-Haynes, E., Sánchez Mora, A. M. and Tagüeña, J. (2015). Public Communication of Science in Mexico: past, present and future of a profession. Public Understanding of Science, 24(1), 38-52. doi.org/ $10.1177 / 0963662514527204$.

SOMEDICyT. (2018). Publicaciones dedicadas a la divulgación de la Ciencia y la Tecnología. Retrieved from www.somedicyt.org.mx/enlaces/publicaciones.html.

SOMEDICyT. (2020). Repositorio Divulga. Acervo de documentos digitales sobre la comunicación de la ciencia. Retrieved from www.somedicyt.org.mx/divulgadores/ repositorio-divulga.

Tonda, J. and Burgos, E. (2007). Análisis y evaluación de las revistas de divulgación. In Proceedings of the X Reunión de la Red de Popularización de la Ciencia y la Tecnología en América Latina y el Caribe (RED POP - UNESCO) y IV Taller 'Ciencia, Comunicación y Sociedad, 9-11 May. San José, Costa Rica.

Tonda, J. et al. (2002). Antología de la divulgación de la ciencia en México. Universidad Nacional Autónoma de México, México, D.F.

Torres, I. (2018). La ciencia para todos del FCE supera los 250 títulos, La crónica, 16. October. Retrieved from www.cronica.com.mx/notas/2018/1097418.html.

UNAM. (2018a). Programa único de especialisaciones en ciencias políticas y sociales. Creación del plan de estudios de la especialización en comunicación pública de la ciencia. UNAM Posgrado, 25 May.

UNAM. (2018b). Posgrado en Filosofía de la Ciencia. Retrieved from www.posgrado. unam.mx/filosofiadelaciencia/programa/campos/comunicacion-de-la-ciencia. html.

Zamarrón, G. (1994). La divulgación de la ciencia en México: una aproximación. Serie Cuadernos de Divulgación 1. México: SOMEDICYT.

\section{Timeline}

\begin{tabular}{|l|l|l|l|}
\hline Event & Name & Date & Comments \\
\hline $\begin{array}{l}\text { First interactive science } \\
\text { centre established. }\end{array}$ & $\begin{array}{l}\text { Museo Tecnológico de la } \\
\text { CFE [Federal Commission } \\
\text { of Electricity] }\end{array}$ & 1970 & $\begin{array}{l}\text { Devoted to electricity, } \\
\text { magnetism and } \\
\text { technology }\end{array}$ \\
\hline $\begin{array}{l}\text { First national (or large } \\
\text { regional) science } \\
\text { festival. }\end{array}$ & $\begin{array}{l}\text { National Week for the } \\
\text { Popularisation of Physics }\end{array}$ & 1985 & $\begin{array}{l}\text { Later the name changed } \\
\text { to National Week for } \\
\text { Science Communication }\end{array}$ \\
\hline
\end{tabular}




\begin{tabular}{|c|c|c|c|}
\hline Event & Name & Date & Comments \\
\hline $\begin{array}{l}\text { An association of } \\
\text { science writers } \\
\text { or journalists or } \\
\text { communicators } \\
\text { established. }\end{array}$ & $\begin{array}{l}\text { AMPECI (Association of } \\
\text { Science Journalists) }\end{array}$ & 1979 & $\begin{array}{l}\text { 1986: Mexican Society } \\
\text { for the Popularisation of } \\
\text { Science and Technology } \\
\text { (SOMEDICyt) for } \\
\text { science communicators }\end{array}$ \\
\hline $\begin{array}{l}\text { First university courses } \\
\text { to train science } \\
\text { communicators. }\end{array}$ & $\begin{array}{l}\text { Diplomado en Divulgación } \\
\text { de la Ciencia, National } \\
\text { Autonomous University of } \\
\text { Mexico }\end{array}$ & 1995 & \\
\hline $\begin{array}{l}\text { First master's } \\
\text { students in science } \\
\text { communication } \\
\text { graduate. }\end{array}$ & $\begin{array}{l}\text { Maestría de Ciencia y } \\
\text { Cultura offered by ITESO } \\
\text { (Western Institute for } \\
\text { Superior Studies) } \\
\end{array}$ & 1998 & \\
\hline $\begin{array}{l}\text { First PhD students in } \\
\text { science communication } \\
\text { graduate. }\end{array}$ & $\begin{array}{l}\text { Posgrado en Filosofía de la } \\
\text { Ciencia [PhD in Philosophy } \\
\text { of Science in Science } \\
\text { Communication] }\end{array}$ & 2003 & \\
\hline $\begin{array}{l}\text { First national } \\
\text { conference in science } \\
\text { communication. }\end{array}$ & Organised by SOMEDICyT & 1991 & \\
\hline $\begin{array}{l}\text { National government } \\
\text { program to support } \\
\text { science communication } \\
\text { established. }\end{array}$ & $\begin{array}{l}\text { Government program } \\
\text { devoted exclusively to } \\
\text { support projects in science } \\
\text { communication. Launched } \\
\text { by CONACyT }\end{array}$ & 2012 & $\begin{array}{l}\text { However, science } \\
\text { communication had } \\
\text { received support } \\
\text { previously as part of } \\
\text { scientific research } \\
\text { projects }\end{array}$ \\
\hline $\begin{array}{l}\text { First significant initiative } \\
\text { or report on science } \\
\text { communication. }\end{array}$ & $\begin{array}{l}\text { COECYT-Michoacán } \\
\text { (J. Padilla and L. Patiño) } \\
\text { diagnosis of science } \\
\text { communication in the state } \\
\text { of Michoacán }\end{array}$ & 2010 & $\begin{array}{l}\text { Diagnosis of other } \\
\text { states were performed } \\
\text { in the following years }\end{array}$ \\
\hline $\begin{array}{l}\text { National Science Week } \\
\text { founded. }\end{array}$ & & 1994 & Organised by CONACYT \\
\hline $\begin{array}{l}\text { A journal completely or } \\
\text { substantially devoted to } \\
\text { science communication } \\
\text { established. }\end{array}$ & Ciencia y Desarrollo & 1975 & Edited by CONACYT \\
\hline $\begin{array}{l}\text { First significant radio } \\
\text { programs on science. }\end{array}$ & $\begin{array}{l}\text { Actividades científicas } \\
\text { [Scientific activities] }\end{array}$ & 1972 & $\begin{array}{l}\text { Conducted by Juan } \\
\text { José Morales }\end{array}$ \\
\hline $\begin{array}{l}\text { First significant TV } \\
\text { programs on science. }\end{array}$ & $\begin{array}{l}\text { Problemas del mundo y del } \\
\text { hombre [Problems of the } \\
\text { world and mankind] }\end{array}$ & 1971 & \\
\hline $\begin{array}{l}\text { First awards for } \\
\text { scientists or journalists } \\
\text { or others for science } \\
\text { communication. }\end{array}$ & $\begin{array}{l}\text { National Award for Science } \\
\text { Communications in honor } \\
\text { of Alejandra Jaidar }\end{array}$ & 1991 & $\begin{array}{l}\text { Organised by } \\
\text { SOMEDICyT }\end{array}$ \\
\hline
\end{tabular}




\begin{tabular}{|c|c|c|c|}
\hline Event & Name & Date & Comments \\
\hline \multirow[t]{8}{*}{$\begin{array}{l}\text { Other significant } \\
\text { events. }\end{array}$} & $\begin{array}{l}\text { A book about comets for } \\
\text { the general public }\end{array}$ & 1681 & $\begin{array}{l}\text { Author Carlos Sigüenza } \\
\text { y Góngora }\end{array}$ \\
\hline & $\begin{array}{l}\text { Centro Universitario de } \\
\text { Comunicación de la Ciencia } \\
\text { (UNAM) was created }\end{array}$ & 1980 & \\
\hline & Launch of Revista Chispa & 1981 & $\begin{array}{l}\text { Popular science } \\
\text { magazine for children }\end{array}$ \\
\hline & $\begin{array}{l}\text { Sundays in Science progam } \\
\text { begins }\end{array}$ & 1983 & Popular science talks \\
\hline & $\begin{array}{l}\text { La Ciencia desde México } \\
\text { [Science from Mexico] }\end{array}$ & 1984 & $\begin{array}{l}\text { Science communication } \\
\text { editorial project is } \\
\text { launched }\end{array}$ \\
\hline & Foundation of SOMEDICYT & 1986 & \\
\hline & Foundation of AMMCCyT & 1996 & \\
\hline & $\begin{array}{l}\text { First public policy for } \\
\text { the support of science } \\
\text { communication in the State } \\
\text { of Michoacán. } \\
\text { National Award for Science } \\
\text { Communication and } \\
\text { Journalism CONACyT }\end{array}$ & 2010 & \\
\hline
\end{tabular}

\section{Contributors}

Dr Elaine Reynoso-Haynes is director of education and research in science communication at the National Autonomous University of Mexico (UNAM).

Susana Herrera-Lima is professor in the Sociocultural Studies Department of ITESO University, Jalisco, México.

Ana Claudia Nepote is associate professor at the National School of Higher Studies at National Autonomous University of Mexico (UNAM) at Morelia, Michoacan, Mexico.

Lourdes Patiño-Barba is president of the Mexican Society of Public Communication of Science and Technology (SOMEDICyT) and senior consultant in Fibonacci Innovation and Scientific Culture. 
This text is taken from Communicating Science: A Global Perspective, edited by Toss Gascoigne, Bernard Schiele, Joan Leach, Michelle Riedlinger, Bruce V. Lewenstein, Luisa Massarani and Peter Broks, published 2020 by ANU Press, The Australian National University, Canberra, Australia.

doi.org/10.22459/CS.2020.24 